\title{
Sex diagnosis of ovine and bovine embryos by enzymatic amplification and digestion of DNA from the $\mathrm{ZFY} / \mathrm{ZFX}$ locus
}

\author{
Peter Bredbacka and JaAna Peippo
}

BRedBaCKA, P. \& PeIPPO, J. 1992. Sex diagnosis of ovine and bovine embryos by enzymatic amplification and digestion of DNA from the ZFY/ZFX locus. Agric. Sci. Finl. 1: 233-238. (Agric. Res. Centre of Finland., Dept. Anim. Breed., SF-31600 Jokioinen, Finland.)

\begin{abstract}
A PCR-based sex determination assay for sheep and cattle embryos was developed using mouse embryos for optimizing the protocol. Samples were lysed either enzymatically or by alkaline treatment followed by enzymatic amplification of DNA from the ZFY/ZFX locus. Sex diagnosis could be done after the digestion of the amplified product by restriction endonucleases. Ovine and bovine embryos could be sexed from biopsies as small as 1-4 cells. Some embryos were split into 2-4 sections, which were amplified separately. Blind trials with such samples demonstrated that the method was highly accurate, even when embryo biopsy was done under farm conditions. The protocol involves an in-built control. This eliminates the need for autosomal control primers, which often inhibit the amplification of the Y-chromosome-specific DNA, especially when a small amount of template is used.
\end{abstract}

Key words: sexing, embryo, sheep, cattle, polymerase chain reaction, restriction fragment length polymorphism

\section{Introduction}

The production of offspring of the desired sex from livestock species is becoming a reality. Although the method of choice would be the separation of Xand Y-chromosome-bearing sperm prior to AI, the only application that can be used in practical conditions at present is to sex embryos in connection with embryo transfer. Various approaches have been used to determine the sex of embryos (for a review, see VAN VLIET et al. 1989), and at present the technique utilizing the polymerase chain reaction (PCR) seems to be the most effective one.

PCR involves the enzymatic amplification of DNA with the help of oligonucleotide primers (SAIKI et al. 1985). By annealing to specific sites of the genomic DNA, the primers define the initiation site of DNA synthesis. When primers anneal on opposite DNA strands, the intervening DNA sequence can be amplified in an exponential manner. This is possible by repeating each amplification cycle, which involves heat denaturation of the DNA, primer annealing and DNA synthesis.

The emergence of thermostabile polymerases for DNA synthesis (SAIKI et al. 1988) has greatly increased the applicability of PCR. The greater speed has made it possible to sex embryos on the same day as embryo recovery and transfer are carried out. Several authors have reported successful amplification of male-specific DNA from embryo biopsies (HANDYSIDE et al. 1989, BRADBURY et al. 1990, HeRR et al. 1990 a, b, SCHRÖDER et al. 1990, BredBacka et al. 1991, Peura et al. 1991, SetiaBUDI and GUSTAVSSON 1991), but further development is needed to make embryo sexing a more straightforward and a more reproducible technique. 
The lack of male-specific amplification product can be caused either by a female biopsy serving as the target or by unsuccessful amplification conditions. To test the amplification success, an autosomal primer pair can be added to the reaction mix. However, this usually leads to a decreased yield of the male-specific product, sometimes at levels below distinction. Usually this is not a problem when a large amount of DNA is available as template, but for sexing embryos only a few cells of the embryo can be sacrificed. Thus, the testing of the method should be done with a limited number of cells, preferably with embryonic cells. This introduces another problem, the availability of embryonic material for optimizing PCR conditions. Livestock embryos are expensive, and embryos from other species can usually not be used because the male-specific primers tend to be more or less species-specific.

This paper presents a PCR protocol for sexing bovine and ovine embryos without the need for autosomal control primers. The amplified sequence is within the ZFY locus. This locus is present on the $\mathrm{Y}$ chromosome of all placental species and has a homologue on the $\mathrm{X}$ chromosome (PAGE et al. 1987). In the mouse, there are two homologues on the Y-chromosome, one on the X-chromosome and a fourth autosomal homologue. Male and female products can be identified due to differences in the restriction fragment length polymorphism (RFLP) of the ZFY/ZFX locus (AASEN and MEDRANO 1990). Mouse embryos were used for optimizing and testing the protocol.

\section{Material and methods}

The oligonucleotide primers were modified after AASEN and Medrano (1990) to match the mouse ZFY sequence as reported by AsHwORTH et al. (1989). The primer sequences were the following: P1-5EZ: 5'-ATA ATC ACA TGG AGA GCC ACA AGC T- 3'

P3-3MZ: 5'-GAG CCT CTT TGG TAT CTG AGA AAG T- 3'

Initial optimization of PCR parameters was done using DNA extracted from tails of female and male mice after overnight incubation in proteinase $\mathrm{K}$ followed by phenol/chlorophorm and ethanol precipitation. The sample amount was approximately $80 \mathrm{pg}$.

Further optimization was carried out with embryos recovered from mice superovulated by standard procedures. Fresh, refrigerator-stored or frozen cattle and sheep embryos were biopsied using the 'scratched-bottom' technique (BREDBACKA 1991). Biopsies were transferred to microtubes with a micropipette having an inner diameter only slightly larger than the diameter of an embryo. In some instances, siliconized pipettes were used. Up to four portions from each embryo were separately amplified and the accuracy of the method was measured in a blind test.

Prior to PCR, the cells were lysed either by 1 hour incubation with proteinase $\mathrm{K}$ at $37^{\circ} \mathrm{C}$ followed by inactivation at $99^{\circ} \mathrm{C}$ ( 8 minutes), or alternatively by a modification of the sperm lysis described by Cur et al (1989). In the latter method, the sample, which is in $1 \mu \mathrm{l}$ of medium (PBS $+4 \mathrm{mg} / \mathrm{ml}$ polyvinylpyrrolidone), is added to $2.5 \mu \mathrm{l}$ of $200 \mathrm{mM}$ $\mathrm{KOH} / 50 \mathrm{mM}$ dithiotreitol and incubated for 10 minutes at $65^{\circ} \mathrm{C}$, followed by neutralization with $2.5 \mu \mathrm{l}$ of $900 \mathrm{mM}$ Tris- $\mathrm{HCl}(\mathrm{pH} 8.3) / 200 \mathrm{mM} \mathrm{HCl}$.

The final PCR mixture contained the sample in 10-100 mM Tris- $\mathrm{HCl}$ (pH 8.8), $1.5 \mathrm{mM} \mathrm{MgCl}_{2}, 50$ $\mathrm{mM} \mathrm{KCl}, 0.01 \%$ gelatin, $0.1 \%$ Triton $\mathrm{X}-100,0.2$ mM dNTPs (dATP, dTTP, dGTP, dCTP), 1.25 IU Taq polymerase (Promega) and $20 \mathrm{pmol}$ of each primer. The reaction mix was overlaid with $25 \mu \mathrm{l}$ of mineral oil (Sigma). The 'Hot Start' technique was used to initiate the reaction: during the first denaturation step, the dNTPs were added through the oil layer of each tube. The final reaction volume was $25 \mu \mathrm{l}$,

The samples were amplified at the following temperatures: initial denaturation at $94^{\circ} \mathrm{C}$ for 3 minutes, then 10 cycles of 1 minute at $94^{\circ} \mathrm{C}$ (denaturation), 50 seconds at $52-60^{\circ} \mathrm{C}$ (annealing) and 30 seconds at $72^{\circ} \mathrm{C}$ (extension). In the following 30 cycles the extension step was 45 seconds, and in the last 10 cycles it was 1 minute. In the last cycle the 
samples were held at $72^{\circ} \mathrm{C}$ for an additional 5 minutes.

After PCR amplification, $10 \mu \mathrm{l}$ from each sample was digested with suitable restriction endonucleases. The ZFY/ZFX product from mice was digested after the addition of $4 \mathrm{IU}$ of HaeIII and $10 \mu \mathrm{l}$ of $10 \mathrm{mM}$ Tris- $\mathrm{HCl}(\mathrm{pH} 7.5), 18.5 \mathrm{mM}$ $\mathrm{MgCl}_{2}$ and $50 \mathrm{mM} \mathrm{NaCl}$ (total reaction volume $20.4 \mu \mathrm{l}$ ). Sheep amplification products were added to $5 \mathrm{IU}$ of SacI in $10 \mu \mathrm{l}$ of buffer A (Boehringer Mannheim). Cattle PCR products were incubated with $5 \mathrm{IU}$ PstI in $10 \mu \mathrm{l}$ of buffer $\mathrm{H}$ (Boehringer Mannheim). All digestions were performed in $37^{\circ} \mathrm{C}$ for $60-90 \mathrm{~min}$, followed by $15 \mathrm{~min}$ at $65^{\circ} \mathrm{C}$ to enhance the separation of the products. DNA fragments were separated by electrophoresis (3\% agarose stained with $0.5 \mu \mathrm{g} / \mathrm{ml}$ ethidium bromide). The fragments were visualized and photographed under UV illumination. In the mouse, HaeIII cuts within the ZFX but not ZFY, yielding two fragments from females (approximately 200 and $250 \mathrm{bp}$ ), whereas in males the uncut ZFY product results in a third band, about 450 bp in size (J.F. MEDRANO, personal communication). In the sheep the ZFY homologue remains uncut with SacI, while the ZFX homologue is digested. Males exhibit three fragments, sized 173, 272 and $447 \mathrm{bp}$, while females lack the largest one (AASEN and MEDRANo 1990). SacI also digests mouse DNA in a similar pattern. In the bovine, the ZFY product is digested but the ZFX homologue is not. Consequently, males show three bands (103, 344 and $445 \mathrm{bp})$ and only one (445 bp) is seen in females (AASEN and MEDRANo 1990). All assays included male and female DNA sample controls (extracted from blood) and a blank control.

\section{Results}

DNA extracted from tails of mice was successfully amplified when $54^{\circ} \mathrm{C}$ was used for primer annealing, but no detectable amplification was observed using $60^{\circ} \mathrm{C}$ as the annealing temperature. Likewise, DNA from mouse, sheep or cattle embryos yielded a PCR product of the expected size using the lower annealing temperature. Biopsies were also successfully amplified, often even when they consisted of one single cell. Although successful amplification was obtained using $52^{\circ} \mathrm{C}$ for primer annealing, $54^{\circ} \mathrm{C}$ appeared to give a better amplification yield.

Enzyme digestion of the PCR products yielded fragments of the expected size (Fig. 1 and 2). In the sheep, a few of the female samples showed a weak band sized approximately $450 \mathrm{bp}$. This was due to incomplete digestion, which could be confirmed after repeated enzyme incubation of such samples. In bovine males, the $103 \mathrm{bp}$ fragment was weaker than the two longer fragments, as could be expected because of the shorter length. Thus the appearance of a 344 bp fragment was the clearest indication of maleness. In most cases it was possible to diagnose the sex from samples as small as 1-4 cells, although the signals in such samples were usually weaker than those obtained from half or quarter embryos.

Accuracy testing was done with sheep embryos, most of which were of poor quality. When the embryo manipulation and the lysis of samples were done under farm conditions, 21 replicated samples were successfully amplified from 14 embryos after splitting into 2-4 portions. No replicates were obtained from 8 embryos. Of all the samples, $67 \%$ (41/61) could be sexed. All replicates from a given embryo yielded identical banding patterns.

When all procedures were done in the laboratory, total amplification success was $68 \%(28 / 41)$ when the samples were lysed in proteinase $\mathrm{K}$. With alkalic treatment the success rate was only $32 \%(7 / 22)$. One misidentification of 15 replicates from $9 \mathrm{em}$ bryos was observed. This contamination was most likely due to the use of the same micropipette for handling all the samples in the laboratory. On the farm, a separate micropipette was used for each sample.

Efficiency (proportion of diagnosable samples) depended on factors such as biopsy size, use of siliconized pipettes, etc. Larger biopsies were more likely to yield detectable amounts of the amplified product. The use of siliconized pipettes appeared to decrease the attachment of embryos to the pipette, thereby improving the efficiency. 


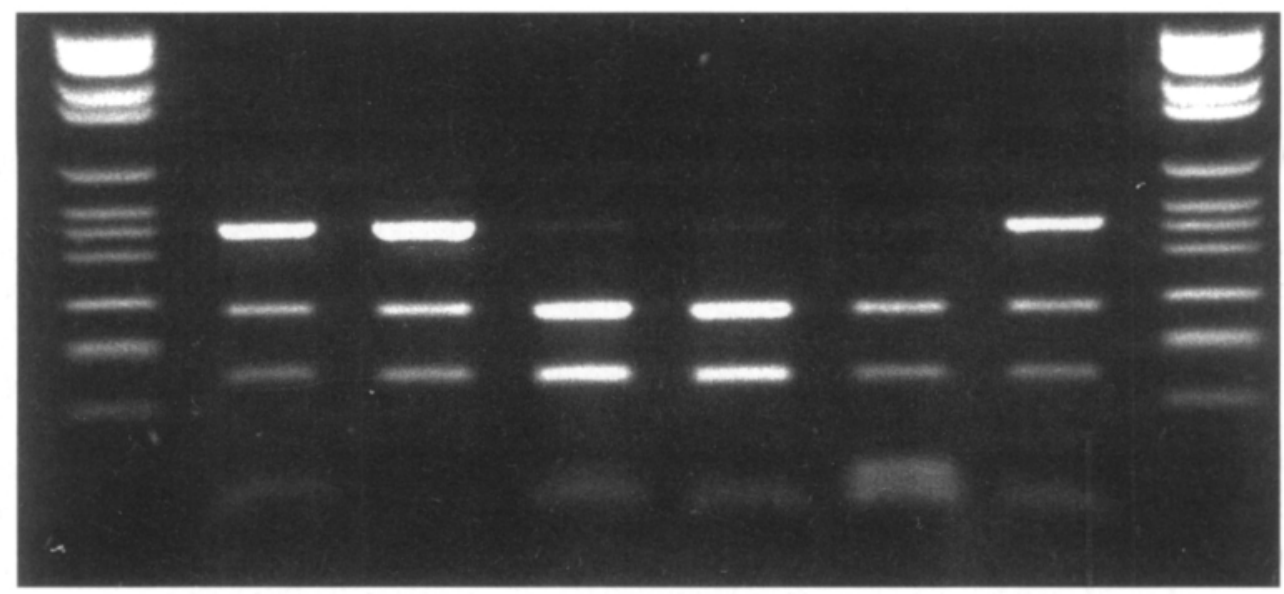

Fig. 1. Banding patterns from digested ZFY/ZFX PCR products of male (lanes 2, 3, 7) and female sheep embryo biopsies (lanes $4,5,6$ ). Samples in lanes $2-7$ were from 5, 3, 7 and 3 blastomeres, a quarter embryo, and a half embryo, respectively. Samples 6 and 7 were prepared under farm conditions. Lanes 1 and 8, molecular weight markers.

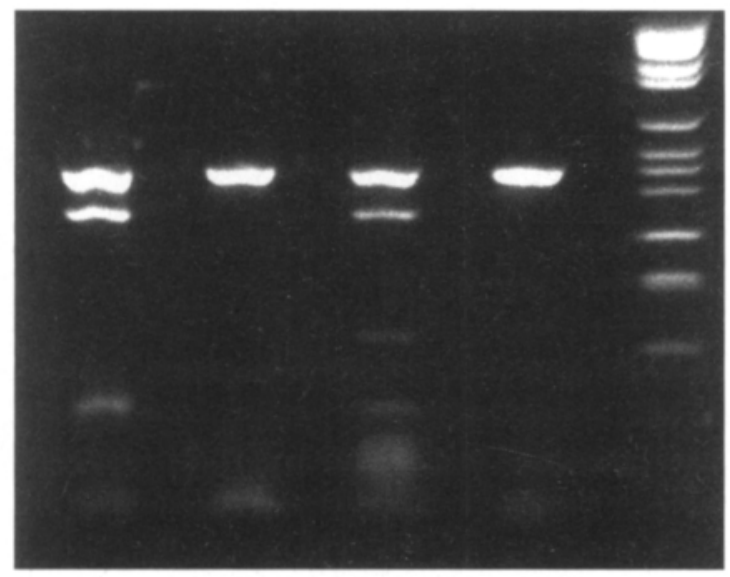

Fig. 2. Banding patterns from bovine male (lanes 1 and 3) and female (lanes 2 and 4) ZFY/ZFX PCR products. Male samples included $10 \mathrm{ng}$ (lane 1) and $1 \mathrm{ng}$ (lane 3) of DNA. Both female patterns are from two-cell-stage embryos. Lane 5 , molecular weight marker.

\section{Discussion}

There are some reports describing livestock embryo sexing based on PCR (HERR et al. 1990 a,b, SCHröder et al. 1990, BREDBACKA et al. 1991, Peura et al. 1991, Setiabudi and Gustafsson 1991), but detailed information is often lacking. This is no doubt partly due to the commercial potential of sexing.

In this paper a thorough protocol is outlined for sexing bovine and ovine embryos. Although sheep embryo sexing results have been published previously (HERR et al. $1990 \mathrm{~b}$ ), this paper is to the authors' knowledge the first to describe in detail PCR-based sexing of embryonic cells in this species.

With the protocol presented in this paper, successful amplification could be obtained from as few as 1-4 blastomeres. This makes it possible to transfer sexed embryos from which only small biopsies have been removed in order to maintain high post-transfer viability. In a recent study (PEIPPO et al., in preparation) 11 of 13 bovine samples $(85 \%)$ could be sexed with the present method when the biopsy size was about $25 \%$ of a morula stage embryo. In the same study, sex was confirmed using another PCR-based sexing method with all embryos (10/10) yielding identical results. In the mouse, two fetuses which were sexed at the preimplantation stage were recovered by caesarean section, both being correctly diagnosed (KANANEN, in preparation). Thus, the method appears to be highly accurate, and with proper handling of biopsies most samples can be diagnosed. 
Since the ZFY locus is not the testis determining gene, there is a minor risk of chromosomal rearrangements leading to ZFY-positive females or vice versa. Caution must be exercised to avoid contamination of any source of placental mammalian DNA, since the distinction between sexes is dependent on species-specific restriction enzymes. For instance, if murine samples are contaminated with bovine DNA, females will be identified as males, since bovine DNA remains undigested with HaeIII. Also, fetal calf serum (or bovine serum albumin) may contain trace amounts of DNA resulting in amplification products. Preliminary trials suggest that this problem can be overcome by exposure to UV light (PeipPo and BredBacka, unpublished). However, the results presented in this paper would suggest that sample contamination is not a major problem.

Compared to the approaches involving control primers, the time required for restriction enzyme digestion is a disadvantage of the protocol presented in this paper. However, in this study we also examined a faster technique to lyse embryonic cells, utilizing alkaline treatment at $65^{\circ} \mathrm{C}$. This chemical approach saves about one hour compared to the enzymatic method, but needs further optimization since only about one third of the samples yielded amplification products in this study.

With the presented protocol, embryo sexing can be performed in about five hours when alkaline lysis of samples is utilized. With faster temperature cycling it is very likely that the protocol can be shortened even more, thus making embryo sexing under field conditions more practical.

Since the primers have a universal nature, initial testing can be performed with mouse embryos. It is quite possible that different laboratories may need to adopt some minor modifications of this protocol. Therefore the possibility of using mouse embryos in the optimization process is an advantage, particularily when the sheep embryo sexing protocol is being optimized, since both species can be sexed with the same protocol. It may be possible to test the conditions with blood or any other source of DNA, but there are some limitations to this. For instance, the control of the amount of template is better with embryos or embryonic cells than with a highly diluted DNA solution, which at very low concentrations may totally lack the template sequence. Furthermore, embryonic cells appear to be more resistant to lysis than many other cell types.

Basically embryos from any mammalian species could be sexed by the method presented in this study, provided that sequence differences exist between the X-and Y-chromosomal products. In ideal situations these differences are recognized by restriction enzymes. Using a variety of enzymes, AASEN and MEDRANo (1990) showed RFLP differences between the sexes in cattle, sheep, goat and humans, but the RFLPs were identical between the sexes in the horse, pig and rainbow trout. However, polymorphisms that remain unobserved after RFLP analysis could be detected on the basis of differential hybridization of allele/homologue specific oligonucleotides. This would require sequence information of the ZFY and ZFX loci.

Acknowledgements. The authors wish to thank Johanna Vilkki for synthesizing the oligonucleotides and Riikka Velmala for extracting DNA from the blood samples. The Finnish-Egyptian sheep breeding project provided all the sheep embryos used in this study.

\section{References}

Aasen, E. \& Medrano, J.F. 1990. Amplification of the ZFY and ZFX genes for sex identification in humans, cattle, sheep and goats. Bio/technology 8: 1279-1281.

Ashworth, A., Swift, S. \& Affara, N. 1989. Sequence of cDNA for murine Zfy-1, a candidate for Tdy. Nucleic Acids Res. 17: 2864.
Bradbury, M.W., Isola, L.M., \& Gordon, J.W. 1990. Enzymatic amplification of a Y chromosome repeat in a single blastomere allows identification of the sex of preimplantation mouse embryos. Proc. Natl. Acad. Sci. USA. 86: 4053-4057.

BREDBACKA, P. 1991. Biopsy of morulae and blastocysts. 
Reprod. Dom. Anim. 26: 82-84.

-, BREDBACKA, K. \& PeIPPO, J. 1991. Experiences of using PCR for sexing bovine embryos. Reprod. Dom. Anim. 26: 75-77.

CUI, X., Li, H., Goradia, T.M., Lange, K., Kazazian, H.H., Galas, D. \& ARNHEIM, N. 1989. Single-sperm typing: Determination of genetic distance between the ${ }^{\mathrm{G}}$-globin and parathyroid hormone loci by using the polymerase chain reaction and allele-specific oligomers. Proc. Natl. Acad. Sci. USA. 86: 9389-9393.

Handyside, A.H., Penketh, R.J.A., Winston, R.M.L., PATtinson, J.K., Delhanty, J.D.A. \& TudDenham, E.G.D. 1989. Biopsy of human preimplantation embryos and sexing by DNA amplification. Lancet ii: 347-349.

Herr, C.M., Holt, N.A., Matthaei, K.I. \& Reed, K.C. 1990 a. Sex of progeny from bovine embryos sexed with a rapid Y-chromosome detection assay. Theriogenology 33: 247.

-, Matthaei, K.I., Petrzak, U. \& Reed, K.C. 1990 b. A rapid Y-chromosome-detecting ovine embryo sexing assay. Theriogenology $33: 245$.

Page, D.C., Moster, R., Simpson, E.M., Fisher, E.M., Mardon, G., Pollack, J., McGilluray, B., De la Chapelle, A. \& Brown, L.G. 1987. The sexdetermining region of the human Y-chromosome encodes a finger protein. Cell 51: 1091-1104.

Peura, T., Hyttinen, J.-M., Turunen, M. \& JÄnne, J. 1991. A reliable sex determination assay for bovine preimplantation embryos using the polymerase chain reaction. Theriogenology 35: 547-555.
Saiki, R.K., Scharf, S., Faloona, F., Mullis, K.B., Horn, G.T., ERlich, H.A. \& ARNhEIM, N. 1985. Enzymatic amplification of B-globin genomic sequences and restriction site analysis for diagnosis of sickle cell anemia. Science 230: 1350-1354.

-, Gelfand, D.H., Stoffel, S., Scharf, S.J., Higuchi, R., Horn, G.T., Mullis, K.B. \& ERLich, H.A. 1988. Primer-directed enzymatic amplification of DNA with a thermostable DNA polymerase. Science 239: 487-491.

SCHRÖDER, A., Miller, J.R., ThOMSen, P.D., Roschlau, K., Avery, B., Poulsen, P., SChmidt, M. \& SChWerin, M. 1990. Sex determination of bovine embryos using the polymerase chain reaction. Animal Biotechnology 1: 121-133.

Setiabudi, R. \& Gustavsson, I. 1991. Establishment of embryo sexing techniques in Sweden. Reprod. Dom. Anim. 26: 78-81.

Van Vliet, R.A., Verringer Gibbins, A.M. \& Walton, J.S. 1989. Livestock embryo sexing: A review of current methods with emphasis on Y-specific DNA probes. Theriogenology 32: 421-438.

\section{Manuscript received January 1992}

Peter Bredbacka

Jaana Peippo

Agricultural Research Centre of Finland

Department of Animal Breeding

SF-31600 Jokioinen, Finland

\title{
SELOSTUS
}

\section{Lampaan ja naudan alkioiden sukupuolilajittelu ZFY/ZFX-lokuksen DNA:n entsymaattisella monistuksella}

\author{
Peter Bredbacka ja JaAna Peippo \\ Maatalouden tutkimuskeskus
}

Lähiaikoina on mahdollista saada haluttua sukupuolta olevia jälkeläisiä käytännön kotieläintuotannossa. Koska siittiöiden lajittelu X- ja Y -siittiöihin ennen keinosiemennystä ei vielä ole tuonut toivottavaa tulosta, on ainoa vaihtoehto tehdä määritys suoraan alkiosta ennen alkionsiirtoa. Alkiosta otetaan näytepala, jonka DNA:sta määritys voidaan tehdä. Sukupuolilajittelu tehdään usein DNA:n spesifisellä monistuksella (PCR) käyttämällä Y-kromosomispesifisten alukkeiden lisäksi autosomaalisia alukkeita, jotka vähentåvăt virhemääritysten todennäköisyyttä. Tällöin reaktio-olosuhteiden optimoiminen muodostuu hankalaksi. Lisăksi käytetyt alukkeet ovat yleensä lajispesifisiä, minkă johdosta optimointi onnistuu vain käyttämällä kyseisen lajin DNA:ta. Tässä tutkimuksessa nämä ongelmat ovat poistettu monistamalla evoluutiossa konservoitunutta ZFY-geeniä. ZFY-geeni on kaikkien istukallisten nisăkkäiden Y-kro- mosomissa, ja sillä on homologi X-kromosomissa. Eri lajien sisällä sukupuolten erottaminen perustuu ZFY-geenin sisällä olevien, lajispesifisten pistemutaatioiden tunnistamiseen restriktio-entsyymien avulla. Entsyymi-käsittelyn jälkeen saadaan kunkin lajin naaraille ja koiraille tunnusomaiset juovastot geelielektroforeesissa. Menetelmä optimoitiin hiiren DNA:lla, ja sen tarkkuus testattiin pilkkomalla lampaan alkioita 2-4 osaan sekä kenttäolosuhteissa että laboratoriossa. Kustakin osasta tehtiin määritys erikseen sokkotestinä. Samalla verrattiin erilaisia näytteen käsittelytapoja parhaan tehokkuuden löytämiseksi. Joissakin tapauksissa solunäytteen entsymaattinen hajotus korvattiin nopeammalla menetelmällä, jossa näyte kuumennettiin emäksisessä liuoksessa. Käytetyllä tekniikalla määritettiin sukupuoli erittäin suurella tarkkuudella lampaan năytepaloista, jopa yhdestă solusta, sekä naudan 1-8 soluisista alkioista. 